DOI: https://doi.org/10.34069/AI/2021.48.12.14

How to Cite:

Asieieva, Y., Trynchuk, O., Furman, A., Melnichuk, I., \& Koval, K. (2021). Emotional intelligence peculiarities of civil servants of Ukraine. Amazonia Investiga, 10(48), 129-137. https://doi.org/10.34069/AI/2021.48.12.14

\title{
Emotional intelligence peculiarities of civil servants of Ukraine
}

\section{Особливості емоційного інтелекту держаних службовців України}

Received: November 16, 2021

Accepted: December 25, 2021

\begin{abstract}
Our work is aimed at studying of emotional intelligence features and leadership qualities of civil servants of Ukraine. The object of study is the emotional intelligence of civil servants. The research methods: theoretical analysis and generalization of socio-psychological literature on the topic of research, psychodiagnostics, and mathematical and statistical methods. The importance of emotional intelligence, leadership qualities in the context of the management model is investigated in the work. The components and mechanisms of influence of emotional intelligence through the manifestation of interpersonal understanding of emotions, empathy, emotional awareness are revealed here. Having conducted an empirical study, we can claim that more than $40 \%$ of surveyed civil servants, regardless of age, position, and work experience have an average level of emotional intelligence, which implies their competence in knowing their own emotions and the emotions of others. It was established that almost $50 \%$ of respondents demonstrate leadership qualities at the level of above-average, while a highly
\end{abstract}

Анотація

Наша робота спрямована на вивчення особливостей емоційного інтелекту та лідерських якостей державних службовців України. Об'єктом дослідження був емоційний інтелект державних службовців. Методи дослідження: теоретичний аналіз та узагальнення соціально-психологічної літератури 3 тематики дослідження, психодіагностики та математикостатистичних методів. У роботі досліджено значення емоційного інтелекту, лідерських якостей у контексті моделі управління. Тут розкриваються компоненти та механізми впливу емоційного інтелекту через прояв міжособистісного розуміння емоцій, емпатії, емоційної усвідомленості. Провівши емпіричне дослідження, можна стверджувати, що понад $40 \%$ опитаних державних службовців, незалежно від віку, посади та досвіду роботи, мають середній рівень емоційного інтелекту, що означає їхню компетентність у пізнанні власних емоцій та емоцій інших. Встановлено, що майже 50\% респондентів демонструють лідерські якості

\footnotetext{
${ }^{49}$ Doctor of Psychological Sciences, senior lecturer at the Department of Psychiatry, Medical and Special Psychology of the State institution «South Ukrainian National Pedagogical University named after K.D. Ushynsky», Odessa, Ukraine.

${ }^{50} \mathrm{PhD}$, Associate Professor of the Department of Language and Psychological and Pedagogical Training of the Odessa National Economic University, Odessa, Ukraine.

${ }^{51}$ Doctor of Psychological Sciences, Dean of the Faculty of Social Sciences and Humanities, Associate Professor of the Department of Theory and Methods of Practical Psychology, State Institution «South Ukrainian National Pedagogical University named after K. D. Ushynsky », Odessa, Ukraine.

${ }^{52} \mathrm{PhD}$, Associate Professor of the Department of Psychiatry, Medical and Special Psychology of the State institution «South Ukrainian National Pedagogical University named after K.D. Ushynsky», Odessa, Ukraine.

${ }^{53}$ Senior Lecturer of the Department of Theory and Methodology of Practical Psychology, of the State institution «South Ukrainian National Pedagogical University named after K.D. Ushynsky», Odessa, Ukraine.
} 
effective type of leadership is chosen by more than $40 \%$ of respondents. The obtained data provide an opportunity to further develop training programs aimed at developing and expanding leadership skills through the improvement of emotional intelligence, the implementation of more humane actions that preserve the human potential of the organization.

Key words: civil servant, emotions, empathy, emotional awareness, emotional intelligence, leadership.

\section{Introduction}

During the period of reforming Ukraine in various fields, an important role in the introduction of new technologies lies with civil servants. Nowadays we observe a tendency to a significant change in the selection criteria for managers and employees of state structural units. Mainly, they are becoming more stringent as the number of real jobs decreases over time, and the requirements for a person applying for a civil servant position become more demanding. The solution to this problem can consist in finding approaches and applying methods of selecting appropriate individuals with existing leadership qualities who will initiate the formation of new types of organizational cultures of structural units of the state and introduce innovative approaches. The new generation of civil servants must show leadership qualities, have a certain level of development of emotional intelligence skills and definition of paradigms of reality perception, which become an effective basis for positive change.

The effectiveness of the implementation of skills for managing modern government depends on certain principles used by managers in their work and the methods they use to apply them. An effective choice of methods and principles makes it possible to ensure the achievement of the desired result with the least effort. The analysis of the above assumes the relevance of determining such a ratio and highlighting the leadership characteristics of employees that are effective in the context of changing the organizational structure of government agencies.

The aim of the study is a determination of emotional intelligence features and leadership qualities of civil servants of Ukraine.

The object of study is the emotional intelligence of civil servants. на рівні вище середнього, тоді як високоефективний тип лідерства обирають більше $40 \%$ респондентів. Отримані дані дають можливість надалі розвивати навчальні програми, спрямовані на розвиток та розширення лідерських навичок шляхом удосконалення емоційного інтелекту, здійснення більш гуманних дій, що зберігають людський потенціал організації.

Ключові слова: державний службовець, емоції, емпатія, емоційна обізнаність, емоційні інтелект, лідерство.

\section{Methodology}

The research methods: theoretical analysis and generalization of socio-psychological literature on the topic of research, psychodiagnostics, and mathematical and statistical methods.

The theoretical method includes theoretical and methodological analysis, generalization of social and psychological achievements on the topic of research, which was aimed at reflecting the current state of the study of emotional intelligence among civil servants.

The psychodiagnostic complex contains the method of measuring the level of emotional intelligence by G. S. Hall, the method of leadership effectiveness by R.S. Nemov, the method of determining the presence of leadership qualities of the personality by J. Welch.

The sample consisted of people who work in various government agencies, hold positions at various levels of the civil service, and have work experience from 1 to 20 years. In total, we interviewed 92 people aged 22 to 42 years.

The study was conducted in accordance with the principles of deontology and bioethics.

\section{Analysis of recent research and publications}

Interest in the interrelation of intelligence, charisma, leadership qualities, emotional intelligence and social authoritative positions of civil servants can be observed in the works of ancient Greek philosophers like Aristotle, Plato, Socrates (Baumeister, \& Tice, 1996, Savchuk, 2017). Closer to a modern understanding of the concept of emotional intelligence, the last began to develop from the concept of social intelligence, which was studied by E. Thorndike, L. Goldberg, G. Eisenk (Eysenck, 1995, Goldberg, 1993, Thorndike, 1920, Thorndike, 


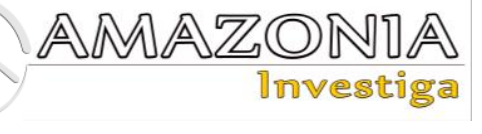

1921), and later representatives of humanistic psychology, P. Salovey and J. Myers (Salovey, \& Mayer, 1994), began to pay attention to this issue. In the twentieth century, emotional intelligence is studied within management, general, social psychology and leadership psychology (Ilyin, 2001, Hunt, 2001, Mayer, 2004, Mayer, \& Salovey, 2005, Waterhouse, 2006).

There is still no single point of view on emotional intelligence. It may be noted that the most common definition is the interpretation of emotional intelligence as a part of social intelligence, which includes the appropriate ability to observe and realize both their own emotions and other people's emotions, and use this information to manage thought process (Garskova, 1999, Gertler, 2003, Lieberman, Jarcho, \& Satpute. 2004, Zeidner, Matthews, \& Roberts, 2009).

The inability to identify and analyze certain emotions that come from others give rise to most social and economic problems in society. Such misunderstandings result in very serious consequences, which determines the importance of studying such issues. The study of emotional intelligence provides answers to questions about the success of a person who did not have certain outstanding talents from birth, but, despite this, still achieved more than another person who, in contrast, had outstanding intellectual abilities from birth, but due to lack of emotionality could not demonstrate them in some way (Bar-On, 1997, Bradberry, \& Greaves, 2009, Lent, Brown, \& Hackett, 1994, Funder, 2006). Deficiencies in emotional intelligence expand the range of risks for a person - from predisposition to depression to the need for violence and unhealthy habits (Markova, Yaremkevych, \& Kozhyna, 2020; Savchuk, 2017; Zeidner, Matthews, \& Roberts, 2009).

Such personality characteristics as self-control, persistence, perseverance can be developed, and, thus, it provides the opportunity to make the best use of the mental potential received from birth. Fundamental ethical attitudes are based on the underlying emotional abilities.

Currently, after the withdrawal from industrial society, the requirements of today dictate the need to effectively shift the perception of the essence of management towards the development of a model of effective cooperation to create corporate ethics and change organizational culture, especially in government.

\section{Results and discussion}

The sample of the study contained individuals who work in various government agencies, hold positions at various levels of the civil service and have work experience from 1 to 20 years. In total, we interviewed 92 people aged 22 to 42 years.

The studied component structure of emotional intelligence consisted of such elements as: emotional awareness, emotional self-control, self-motivation, empathy, control of other people's emotions. According to the method of determining the level of emotional intelligence by $\mathrm{G}$. S. Hall obtained the following results, which are given in table 1 .

Table 1.

Peculiarities of emotional intelligence of the subjects.

\begin{tabular}{lllllll}
\hline & $\begin{array}{l}\text { Emotional } \\
\text { awareness }\end{array}$ & $\begin{array}{l}\text { Emotional } \\
\text { self-control }\end{array}$ & $\begin{array}{l}\text { Self- } \\
\text { motivation }\end{array}$ & Empathy & $\begin{array}{l}\text { Control of } \\
\text { other people's } \\
\text { emotions }\end{array}$ & Total \\
\hline $\begin{array}{l}\text { High level } \\
\text { Middle }\end{array}$ & 27.47 & 9.62 & 37.24 & 33.43 & 36.54 & 28.86 \\
$\begin{array}{l}\text { level } \\
\text { Low level }\end{array}$ & 59.07 & 32.69 & 52.72 & 48.08 & 42.31 & 46.97 \\
\hline
\end{tabular}

Note: The data in the table is given as a percentage. Source: (own authorship)

It was found that the majority of respondents $46.97 \%$ have an average integrative level of emotional intelligence, which provides a good level of knowledge of the emotional component of managerial relationships. The level of "emotional awareness" (59.07\% of respondents), "self-motivation" $(52.72 \%$ of respondents $)$, "empathy" (4.08\% of respondents) and "control of other people's emotions" (42.31\% of respondents) are mostly average among civil servants.

Only $9.62 \%$ of respondents had a high level of "emotional self-control", which in most cases implies a low development level of emotional lability, the ability to quickly avoid the impact of 
negative emotions caused by external or internal factors, including reactive reactions to images and negativity.

The results show us that those who represent public authorities do not have a high enough level of emotional intelligence to conflict-free, calmly, minding the individual characteristics of those who sought help convey the position of power. The ability to influence and control the emotions of others also has only an average level of manifestation, which requires refinement and the direction of programs on the development of this characteristic.

At the next stage, the results obtained by the method of J. Welch were analyzed (Pic. 1).

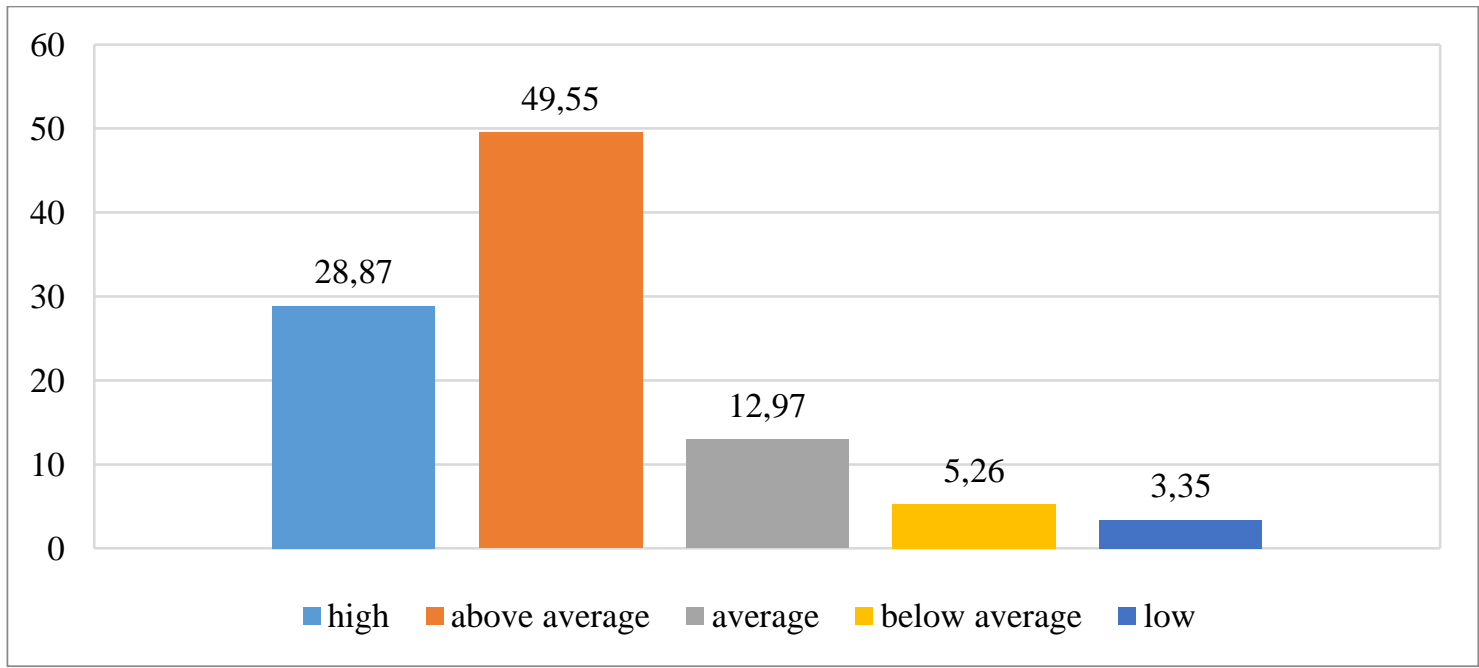

Pic. 1. The presence of individual's leadership qualities according to the method of J. Welch Source: (own authorship)

According to the data obtained, the gradation of leadership qualities of the individual by the method of J. Welch shows a wide differentiation of indicators from low to high with personification on the indicators "above average" and "below average", which increases the validity of the methodology and objectivity of results. It was found that the majority of respondents $(4, .55 \%)$ had indicators of personal characteristics for leadership above average, which implies high mental and emotional characteristics and indicates the ability to build a team with effective management, but with certain personal characteristics that need improvement.

At the same time, $28.87 \%$ of respondents had high personal characteristics of leadership, which determines the presence of pronounced qualities, in particular: energy, ability to inspire others, the desire to win, discipline and responsibility. All these qualities are necessary for people who are representatives of state power, especially in the latest reform conditions.

$12.97 \%$ of respondents had an average level of personal characteristics of leadership. The level below the average was only $5.26 \%$ of respondents, and the low level was found in $3.35 \%$, which indicates that a certain number of civil servants are unable to perform functions related to the manifestation of leadership qualities.

The next psychodiagnostic technique that was chosen is "Leadership Effectiveness Test by R. S. Nemov". The results are given in Pic. 2. 


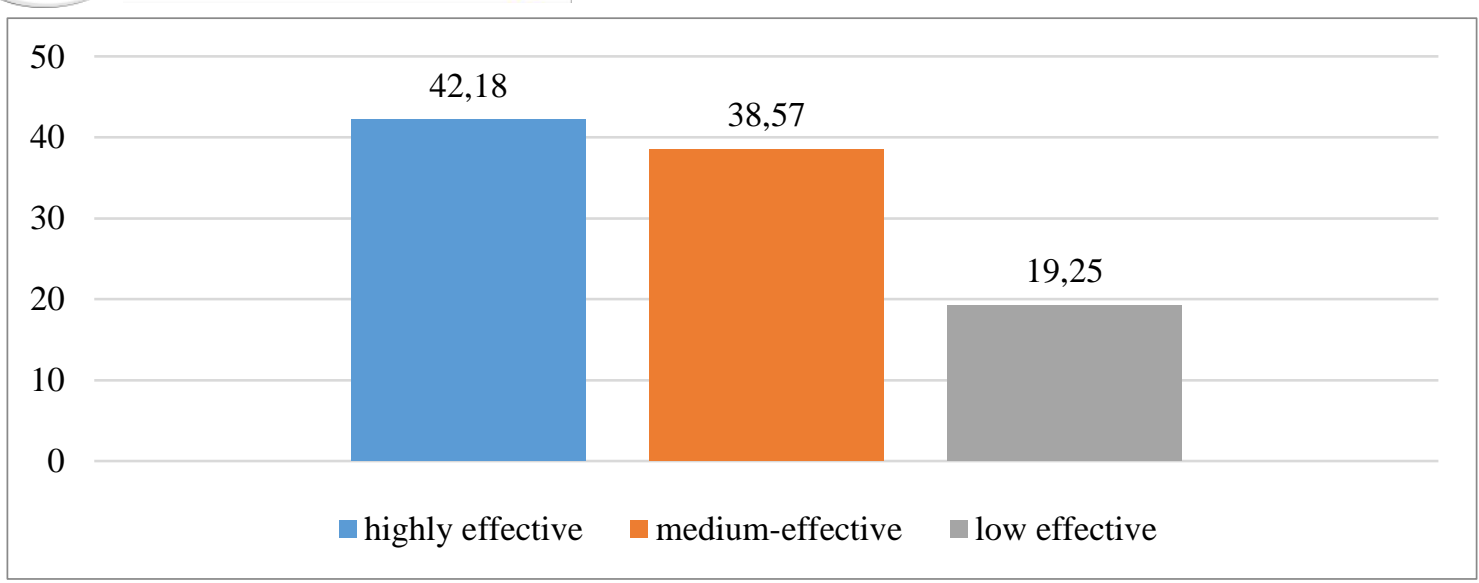

Pic. 2. The results of determining the leadership effectiveness.

Source: (own authorship)

According to the gradation of indicators of leadership effectiveness in the practice of civil servants of different levels of subordination due to the method of R. S. Nemov a scale with the following three definitions is introduced: "low effective", "medium-effective", "highly effective". Conforming to the results, it was found that the majority of surveyed civil servants $42.18 \%$ demonstrated a highly effective and medium-effective type of leadership (38.57\% of respondents), which was expressed in practical activities, manifestation of leadership qualities, ability to influence the opinion of others, to motivate, to change the organizational culture for the better. Such characteristics of civil servants are especially necessary in the period of global reform of the entire state apparatus of the country.
Low effective type of leadership was found in $19.25 \%$ of respondents, which points out the need for further control of individual psychological qualities of applicants for civil servants, as those who do not have the skills of effective leadership should not hold such positions.

To establish the relationship between the level of emotional intelligence and leadership qualities of civil servants of different levels of subordination, we investigated the possible correlations, by determining the correlation coefficient of $\mathrm{K}$. Pearson. At the first stage of defining the interrelation, we explored the general integrative indicators for each of the selected psychodiagnostic techniques (Table 2).

Table 2.

Matrix of correlation coefficients of K. Pearson between integrative indicators of selected methods.

\begin{tabular}{|c|c|c|c|}
\hline & $\begin{array}{l}\text { Integrated } \\
\text { total score of } \\
\text { G. S. Hall's } \\
\text { method }\end{array}$ & $\begin{array}{l}\text { Integrated total } \\
\text { score of J. } \\
\text { Welch's method }\end{array}$ & $\begin{array}{l}\text { Integrated total } \\
\text { score of } \\
\text { R. S. Nemov's } \\
\text { method }\end{array}$ \\
\hline \multirow{3}{*}{$\begin{array}{l}\text { Integrated total score of G. S. Hall's method } \\
\text { Integrated total score of J. Welch's method } \\
\text { Integrated total score of R. S. Nemov's } \\
\text { method }\end{array}$} & $1.000^{* * * *}$ & -0.068 & $0.712^{* * *}$ \\
\hline & -0.068 & $1.000^{* * * *}$ & 0.069 \\
\hline & $0.712^{* *}$ & 0.069 & $1.000^{* * * *}$ \\
\hline
\end{tabular}

Note: $*-\mathrm{p} \leq 0.05 ; * *-\mathrm{p} \leq 0.01 ; * * *-\mathrm{p} \leq 0.000$

Source: (own authorship)

A positive reliable relationship was established between the integrated total score according to the method of determining the level of emotional intelligence by G. S. Hall and the method of leadership effectiveness by R. S. Nemov $(\mathrm{r}=0.712 ; \mathrm{p} \leq 0.01)$. The obtained results indicate a direct relationship between emotional intelligence and the level of leadership effectiveness, which allows us to explore this relationship in more detail on the subscales of selected methods (Table 3). 
Table 3.

Matrix of correlation coefficients of K. Pearson between the level of emotional intelligence and the level of leadership effectiveness.

\begin{tabular}{llllll}
\hline Methods subscales & $\begin{array}{l}\text { Emotional } \\
\text { awareness }\end{array}$ & $\begin{array}{l}\text { Emotional } \\
\text { self-control }\end{array}$ & $\begin{array}{l}\text { Self- } \\
\text { motivation }\end{array}$ & Empathy & $\begin{array}{l}\text { Control of } \\
\text { other } \\
\text { people's } \\
\text { emotions }\end{array}$ \\
\hline $\begin{array}{l}\text { Highly effective } \\
\text { Medium effective }\end{array}$ & $0.601^{* *}$ & 0.224 & 0.099 & -0.279 & $0.304^{*}$ \\
Low effective & $0.673^{* *}$ & 0.266 & $0.386^{*}$ & 0.258 & 0.463 \\
\hline
\end{tabular}

Note: $*-\mathrm{p} \leq 0,05 ; * *-\mathrm{p} \leq 0,01 ; * * *-\mathrm{p} \leq 0,000$.

Source: (own authorship)

As stated by the results of a detailed analysis of the data, it can be stated that emotional awareness of the individual has an impact on the level of effectiveness of leadership qualities due to a positive relationship between highly- and medium-effective leadership and emotional awareness of personality $(r=0.601$ and $r=0.673$; $\mathrm{p} \leq 0.01$ (respectively)). A slight positive and significant correlation was found between selfmotivation and medium-effective type of leadership $(r=0.386 ; p \leq 0.05)$, which shows that the higher the level of inner motivation of the individual, the more effective type of leadership the individual chooses. Thus, with the faith and internal motivation of the individual in the business in which s/he is engaged, there are internal mechanisms for finding the most effective style of management and organization of people who can be involved in achieving the goal. The ability to control the emotions of others has a direct reliable relationship with a highly effective type of leadership $(r=0.386 ; p \leq 0.05)$, which shows that the higher the level of ability to recognize and direct the identified emotions of others in the correct and effective direction of their implementation the higher will be the level of the chosen effective type of manifestation of leadership position, which contributes to the faster execution of the tasks. However, it must be mentioned that empathy does not contribute to the choice of an effective type of leadership $(\mathrm{r}=0.304 ; \mathrm{p} \leq 0.05)$.

\section{The discussion}

It should be noted that the difficulties of managing one's emotions acquire special significance if professional activity involves "emotional work" - the required expression of certain emotions from the employee in professionally significant situations (Hochschild, 1983). A. Grandey, developing the concept of emotional work in the framework of organizational psychology, suggests considering this concept not as a mandatory requirement of the organization to the employee to express certain emotions, but as efforts to regulate the emotions that the employee takes when performing professional duties (Grandey, \& Melloy, 2017). These efforts are more related to the concept of emotional regulation and the choice of strategies for the regulation of emotions: either rethink, give a cognitive assessment of emotions and thus manage them, or focus on the expression of emotions and strengthen defensive techniques to suppress unwanted emotions (Gross, 1998). In other words, the question arises of another important aspect that is directly related to emotional regulation - emotional intelligence - which characterizes the abilities and skills of understanding, managing and expressing emotions (Lyusin, 2009; Pankova, 2010; Mayer et al., 2008).

In some studies we find that the development of emotional intelligence, perception and awareness of the specifics of the principles of determining its level by research through the methods of Hall N., Lusin D.V., Vyshnyakova N., Ketel R. identified a significant impact of physiological and pathological features on personality consciousness (Mendelevich, \& Pyrkova, 2015).

Studies have noted that in people with neurotic disorders, the level of emotional intelligence is lower, in particular intrapersonal, which is manifested mainly by a poorly developed ability to control personal emotions. The structural components of interpersonal emotional intelligence in the subjects of this group are interconnected with such personal characteristics as conformism and practicality. In the group of people without neurological disorders, the average level of emotional intelligence was revealed. Most of the structural components of interpersonal intelligence and creativity are interconnected with flexibility, an integrative personality trait that allows them to successfully adapt. At the same time, no differences in the 


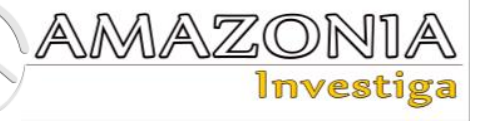

level of creativity of the subjects were found (Mendelevich, \& Pyrkova, 2015).

When studying the level of emotional intelligence among sales managers, it was found that the level of emotional intelligence is associated with a decrease in the level of subjective stress and, in addition, with improved health and productivity (Slaski, \& Cartwright, 2002). Interestingly, these positive effects are observed only in situations of high uncertainty and conflict associated with the work role (for example, the employer's requirements are unclear, there is a conflict between the requirements and the seller's needs) (McFarland, Rode, \& Shervani, 2016).

Thus, based on the meaningful characteristics of emotional intelligence, it can be attributed to the general problematic field of emotional regulation: recognition, processing, forecasting, expression of emotions, using different - adaptive and non-adaptive - strategies for managing them, modulating them under normal and stressful conditions. This rather broad interpretation of the concept of emotional regulation is consistent with the modern approach to the definition of this concept, which focuses on the individual's desire to influence the range of experienced emotions: from the moment of their recognition to their expression (Rottenberg, \& Gross, 2007).

Emotional intelligence refers to correctly identifying, managing, and expressing emotions. Emotional intelligence mediates the relationship between emotional demands and exhaustion, and high emotional intelligence influences the effectiveness of emotional labor strategies (deep versus shallow depiction of emotions) (Peng, Wong, \& Che, 2010). The contribution of the components of Emotional Intelligence to the performance of work by civil servants is mediated by strategies of emotional work: authentic strategies are associated with the perception of an employee as reliable and trustworthy and have a positive effect on the willingness of citizens to continue to communicate with him, while superficial strategies act in a negative quality. A special role in the application of deep strategies when communicating with government officials is played by such a component of emotional intelligence as the understanding of emotions (Delpechitra, \& Beeler, 2018).

In civil servants, high emotional intelligence reduces the level of stress associated with the work role, which is reflected in three possible consequences of stress: 1) the level of emotional exhaustion decreases; 2) an employee "does not get stuck" on negative emotions when working with citizens; 3 ) and he is able to continue to do his job well and effectively (the authority of the state increases).

\section{Conclusions}

Having conducted an empirical study of the characteristics of emotional intelligence and leadership qualities of civil servants of Ukraine, we can claim that more than $40 \%$ of surveyed civil servants, regardless of age, position, and work experience have an average level of emotional intelligence, which implies their competence in knowing their own emotions and the emotions of others. The results indicate that civil servants mostly provide awareness, understanding of their own emotions and are able to analyze them, as well as have the ability to manage them through internal influence and, accordingly, increase personal leadership and the effectiveness of others. The demonstrated ability to empathize with another person's state and willingness to provide support do not always lead to the adoption of the right type of leadership. It is worth noting, that there is a significant percentage of respondents who have a low "ability to emotional self-control" subscale which, in most cases, implies a low development of emotional lability, the ability to quickly avoid negative emotions caused by external or internal factors, including reactive reactions to images and negative. But the main results of the study were not affected by the level of determination of this indicator.

It was established that almost $50 \%$ of respondents demonstrate leadership qualities at the level of above-average, while a highly effective type of leadership is chosen by more than $40 \%$ of respondents. This assumes high mental and emotional characteristics, the ability to build a team with effective management, but with the presence of certain personal characteristics that need improvement. Consequently, it can be stated that currently most civil servants are endowed with such individual psychological characteristics that allow them to successfully implement the ideas and tasks set by the state. Due to the correlation analysis, it is possible to emphasize the need to develop emotional awareness, as its presence has a positive effect on choosing an effective type of leadership. The obtained results lead us to further study of the selected issues in order to identify additional factors that may contribute to the development of emotional intelligence and leadership qualities. The formative training 
programs for civil servants should appear taking into account the last mentioned.

\section{Bibliographic references}

Bar-On, R. (1997) Development of the Ваг-On EQ-I: A measure of emotional intelligence. Paper presented at 105th Annual Convention of American Psychological Association. Psicothema, Vol. 18, supl., pp. 13-25, URL: http://www.psicothema.com/pdf/3271.pdf (in English).

Bradberry, T., \& Greaves, J. (2009), Emotional intelligence 2.0. San Diego: Talent Smart, 255 p (in English).

Baumeister, R. F., \& Tice, D. M. (1996). Rethinking and reclaiming the interdisciplinary role of personality psychology: The science of human nature should be the center of the social sciences and humanities. Journal of Research in Personality, 30(3), 363-373. URL: https://doi.org/10.1006/jrpe.1996.0025 (in English).

Delpechitra, D., \& Beeler, L. (2018) Faking it: salesperson emotional intelligence influence on emotional labor strategies and customer outcomes. Journal of Business and Industrial Marketing, 33(1), 53-71. URL: https://www.sciencegate.app/document/10.1 108/jbim-08-2016-0170 (in English).

Eysenck, G.Yu. (1995) Concept and definition of intelligence. Psychological issues, V. 1., p. 111-131 URL: http://raai.org/library/books/aizenk/aizenk.ht m (in Russian)

Funder, D. C. (2006). Towards a resolution of the personality triad: Persons, situations, and behaviors. Journal of Research in Personality, 40(1), 21-34. URL: https://doi.org/10.1016/j.jrp.2005.08.003 (in English).

Gertler, B. (Ed.). (2003). Self Knowledge (Winter 2003 Edition ed.), U. Tennessee/Martin, http://plato.stanford.edu/archives/win2003/e ntries/davidson/ (in English).

Goldberg, L. R. (1993). The structure of phenotypic personality traits. American Psychologist, 48, p. 26-34. URL: http://psych.colorado.edu/ carey/courses/ps yc5112/readings/psnstructure_goldberg.pdf (in English).

Garskova, G.G. (1999). "Introduction of the concept of "emotional intelligence" in psychological theory", Theses of the scientific conference. "Ananiev readings", Izd-vo SPb. un-ta, SPb. Russia, p. 26. URL: http://elib.gnpbu.ru/textpage/download/html/ ?bookhl=\&book=ananyevskie_chteniya_199 9 (in Russian)

Grandey, A.A., \& Melloy, R.C. (2017) The state of the heart: Emotional labor as emotion regulation reviewed and revised. Journal of Occupational Health Psychology, 22(3), 407-422.

URL: https://pubmed.ncbi.nlm.nih.gov/28150996/ (in English).

Hochschild, A.R. (1983) The managed heart: Commercialization of human feeling, by Arlie Russell Hochschild. Berkeley, CA: University of California Press, p. 307. DOI: https://onlinelibrary.wiley.com/doi/10.1002/ pam.4050030365 (in English).

Hunt, E. (2001). Multiple views of multiple intelligence. PsycCRITIQUES, 46, 5-7. DOI: $10.1037 / 002513$

URL: https://www.researchgate.net/publication/24 7430273_Multiple_Views_of_Multiple_Inte lligence (in English).

Ilyin, E.P. (2001) Emotions and Feelings. Saint Petersburg: Peter, p. 242-244.URL: https://www.docme.su/doc/1766792/il._ine.p.---e-mocii-i-chuvstva--2001-.pdf (in Russian)

Lent, R. W., Brown, S. D., \& Hackett, G. (1994). Toward a unifying social cognitive theory of career and academic interest, choice, and performance. Journal of Vocational Behavior, 45, 79-122. URL: https://www.semanticscholar.org/paper/Tow ard-a-Unifying-Social-Cognitive-Theory-ofCareer-Lent-

Brown/9ba5f910f082d15d9234729d3a78d42 89b902100 (in English).

Lieberman, M. D., Jarcho, J. M., \& Satpute, A. B. (2004). Evidence-Based and Intuition-Based Self-Knowledge: An fMRI Study. Journal of Personality and Social Psychology, 87(4), 421-435. URL: https://doi.org/10.1037/0022-3514.87.4.421 (in English).

Markova, M., Yaremkevych, R., Kozhyna, H., Yudin, M., \& Mukharovska, I. (2020). Psychosomatic correlates and psychoemotional disorders in patients with dermatologic disorders and chronic itch. The journal of the European psychiatric association, Vol. 63s, p. 350 URL: http://repo.knmu.edu.ua/handle/123456789/ 27421 (in English).

Mayer, J.D., \& Salovey, P. (2005) Emotional intelligence. University of New Hampshire, URL:

http://www.unh.edu/emotional_intelligence/( in English).

Mayer, J. D. (2004) "What is Emotional Intelligence?" UNH Personality Lab, 8. URL: 


\section{AMAZONIA \\ Drvestiga}

https://scholars.unh.edu/personality_lab/8 (in English).

McFarland, R. G., Rode, J. C., \& Shervani, T. A. (2016). A contingency model of emotional intelligence in professional selling. Journal of the Academy of Marketing Science, 44(1), 108-118.

URL: https://doi.org/10.1007/s11747-015-0435-8 (in English).

Mendelevich, V. D., \& Pyrkova, K. V. (2015) Research of emotional intelligence and creativity in patients with neurotic disorders: Electronic Journal "Modern problems of science and education": Scientific article, 3. URL: https://scienceeducation.ru/ru/article/view?id=20326 (in Russian)

Peng, K.Z., Wong, C.S., \& Che, H.S. (2010) The missing link between emotional demands and exhaustion. Journal of Managerial Psychology, 25(7), 777-798. URL: https://www.econbiz.de/Record/the-missinglink-between-emotional-demands-andexhaustion-peng-kelly/10008825854 (in English).

Rottenberg, J., \& Gross, J. J. (2007). Emotion and emotion regulation: A map for psychotherapy researchers. Clinical Psychology: Science and Practice, 14(4), 323-328.

URL: https://doi.org/10.1111/j.14682850.2007.00093.x (in English).

Salovey, P., \& Mayer, J. D. (1994). Some final thoughts about personality and intelligence. In R. J. Sternberg \& P. Ruzgis (Eds.), Personality and intelligence Cambridge

University (pp. 303-318). Press. https://psycnet.apa.org/record/1994-97614011_(in English)

Savchuk, M.R. (2017) Theoretical foundations of the advancement of emotional intelligence. Economics is effective, V. 5. URL: http://www.economy.nayka.com.ua/?op=1\& $\mathrm{z}=5608$ (in Russian)

Shevchenko, R., Popovych, I., Spytska, L., Bosov, P., Zinchenko, S., Mateichuk, V., y Blynova, O. (2020). Comparative analysis of emotional personality traits of the students of maritime science majors caused by long-term staying at sea. Revista Inclusiones, Vol. 7 num Especial, 538-554.

Slaski, M., \& Cartwright, S. (2002). Health, performance and emotional intelligence: An exploratory study of retail managers. Stress and Health: Journal of the International Society for the Investigation of Stress, 18(2), 63-68. URL: https://doi.org/10.1002/smi.926 (in English).

Thorndike, E. L. (1920). Intelligence and its use. Harper's Magazine, 140, 227-235. (in English).

Thorndike, E. L., et al. (1921). Intelligence and its measurement: A symposium. Journal of Educational Psychology, 12, 123-147, 195-216, 271-275. (in English).

Waterhouse, L. (2006). Multiple intelligences, the Mozart effect, and emotional intelligence: A critical review. Educational Psychologist, 41 207-225. DOI: 10.1207/s15326985ep4104_1 (in English).

Zeidner, M., Matthews, G., \& Roberts, R. D. (2009) What we know about emotional intelligence: how it affects learning, work, relationships, and our mental health. London: A Bradford book, 464 p. (in English). 